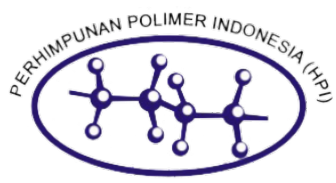

\title{
The Role of Partially Hydrolyzed Polyvinyl Alcohol to the Enhance- ment of the Electrical Conductivity of Conductive Polymer
}

\author{
Mas Ayu Elita Hafizaha, Nayaka Wicaksana ${ }^{a}$, Suparno $^{a}$, Andreas $^{b}$, Azwar Manaf $^{a}+$ \\ This is the report of preliminary studies on the properties of polymerization solution containing 1,5 , and $10 \%$ polyvinyl \\ alcohol (PVA). The degree of polymerization was divided into three categories of respectively low, medium, and high. The \\ $\mathrm{pH}$ value of all solutions was found almost similar, which approximately in the range 5.0-6.5. While the viscosity exhibited \\ values in the range 1.20-1985 mPa s depends on the concentration and the degree of polymerization. The lower solid \\ content evaluation indicated a faster dissolution rate of PVA when compared with those of medium and high. The PVA \\ dissolves completely in less than 10, 180, and 220 minutes for 1, 5, and $10 \%$ of the solution, respectively. The solid content, \\ which is the indicator of the solubility property of solution has resulted in a deviation of less than $0.1 \%$ between that of \\ experimental and theoretical for each concentration. This report also discusses thin film properties, including the \\ electrical conductivity value of each PVA solution against time during the dissolving process.
}

Penelitian ini merupakan studi pendahuluan tentang sifat-sifat larutan polimer yang mengandung 1, 5 dan 10\% polivinil alkohol (PVA). Tingkat polimerisasi dibagi menjadi tiga kategori masing-masing rendah, sedang dan tinggi. Nilai pH dari semua larutan ditemukan hampir serupa, yaitu kisaran 5,0-6,5. Sementara viskositas menunjukkan nilai dengan kisaran 1,20-1985 mPa s tergantung pada konsentrasi dan tingkat polimerisasi. Hasil analisis kandungan padatan yang rendah menunjukkan laju penguraian PVA yang lebih cepat jika dibandingkan dengan yang sedang dan tinggi. PVA larut seluruhnya dalam waktu kurang dari 10, 180 dan 220 menit masing-masing untuk 1, 5 dan 10\% dari larutan. Kandungan padat, yang merupakan indikator sifat kelarutan, telah menghasilkan penyimpangan kurang dari $0,1 \%$ antara eksperimental dan teoritis untuk setiap konsentrasi. Penelitian ini juga membahas sifat-sifat film tipis, termasuk nilai konduktivitas listrik dari setiap larutan PVA terhadap waktu selama proses pelarutan.

16 September 2019

Received in revised form

26 December 2019

Accepted

28 December 2019

Published

31 December 2019

DOI: $10.37889 / \mathrm{mpi} .2019 .22 .2 .2$

Keywords: Partially hydrolyzed of Polyvinyl alcohol, polyvinyl alcohol, solid content, thin film, viscosity.

\section{Introduction}

Polymeric materials have offered various uses and many possibilities for applications in a variety of consumer goods, which are cheaper to use throughout the world. In recent years, the bio and electricity industry has also shown other applications of polymeric materials to be developed as biodegradable materials. ${ }^{1-5}$ Polyvinyl alcohol (PVA) is a polymer material that has organic and electrical properties, is a synthetic material which soluble in water and has the ability to form films. PVA also has good and interesting chemical, physical, electrical, and mechanical properties. ${ }^{6}$ One of the advantages of PVA is its ability to form fibers so that PVA meets the requirements for further research on conductive polymers for electricity use. ${ }^{7,8}$ Other conductive polymers besides PVA are polypyrrole (PPy) and polyaniline (PANI). ${ }^{9,10}$

Polyvinyl alcohol (PVA) is a type of polymer made from the hydrolysis reaction of polyvinyl acetate instead of the vinyl alcohol monomer itself. Due to these hydrolysis reactions caused, the PVA

\footnotetext{
a. Postgraduate Program of Materials Science, Faculty of Mathematics and Natural Science, Universitas Indonesia, Jl. Salemba Raya No.4, Jakarta 10430, Indonesia.

b.Indonesian Institute of Sciences, LIPI, Komplek PUSPITEK, Serpong, Banten 15314, Indonesia.

† Corresponding author: azwar@ui.ac.id.
}

is classified depending on the degree of hydrolysis. ${ }^{11}$ The molecular weight of the type hydrolysis level will affect the length of the molecular chain, hence known for PVA type is a low, medium, and a high degree of polymerization. ${ }^{12}$ This study explored the attractive physical, chemical, and electrical properties of partially hydrolyzed PVA with three different degrees of polymerization.

The solution containing PVA has different properties when dissolved with water; its solubility depends on the level of hydrolysis, the degree of polymerization, concentration, and other supporting parameters. ${ }^{13}$ The known levels of hydrolyzed PVA are Fully Hydrolyzed Polyvinyl Alcohol (PVA-FH) with 97-99\% hydrolyzed polymers and Partially Hydrolyzed Polyvinyl Alcohols (PVA-PH) with 85$89 \%$ hydrolyzed polymers. These two PVA parameters also vary in the degree of polymerization (based on molecular weight). ${ }^{14}$ PVA$\mathrm{PH}$ is commonly used as a barrier to moisture protection for many things such as food and medical capsules, whereas PVA-FH has been known to be used as a component of electrospun fiber. ${ }^{15,16}$ Increasing textile strength, elastic ability, and reshaping materials are some of the capabilities offered by PVA. The properties of the coating are further investigated. The PVA coating must tend to have properties similar to the coated material. Differences in properties between layers and coated materials cause destructive arrangements. The optimal layer is known by examining certain types of 
PVA and its parameters and materials. As for the conductive polymer coating, PVA-PH tends to match the mechanical properties and characteristics of the conductive polymer. ${ }^{17}$

In recent years, most of PVA uses for improving material defect. Embedding Zr-Ac phosphorus adsorbent was one of its ability to improve material defects. ${ }^{18}$ Other research has shown that PVA has the conductive ability and able to get doped with another substance such as $\mathrm{Na}_{2} \mathrm{SO}_{4}$. The PVA and $\mathrm{Na}_{2} \mathrm{SO}_{4}$ were connected with the composite relation to show additive conductivity. This indicates that PVA is a stable polymer material with longer electrical stability. ${ }^{5}$ The ability to cover the material defect and its conductivity show PVA promising substance to create a coating of conductive polymer. PANI and Ppy were known as a good conductive polymer material, but those substances cannot be shaped as it is only a powder. Substance shaping of PVA studied further for PANI and PPy materials. ${ }^{19}$

The PVA is made from hydrolysis reaction of polyvinyl acetate (PVAc) in an alcohol such as methanol and treating it with an alkaline catalyst such as sodium hydroxide. ${ }^{14,20}$ The objective of this research is to characterize the chemical, physical, electrical, and mechanical properties of each PVA type and to study the properties of the enhancement electrical conductivity of the PVA. The characterization of the PVA solution-phase through important parameters such as dissolution rate at room temperature, solid content, viscosity, $\mathrm{pH}$ and conductivity value, and molecule structure. The observation was conducted to PVA with a low, medium, and high degree of polymerization in three different concentrations 1,5 , and $10 \%$, respectively.

\section{Experimental Methods}

\section{Materials}

Several materials are used during the observation activity. There are three types of polyvinyl alcohol (PVA) powder ex. Kuraray Poval with purity $99.9 \%$. Those types of PVA are PVA partially hydrolyzed ( $88 \%$ mol degree of hydrolysis) with a low polymerization degree, PVA partially hydrolyzed ( $88 \%$ mol degree of hydrolysis) with a medium polymerization degree and PVA partially hydrolyzed $(88 \% \mathrm{~mol}$ degree of hydrolysis) with high polymerization degree. High quality of demineralized water (DW) was used as a solvent during the dissolution process.

\section{Method}

The specimens used to be three kinds of partially hydrolyzed PVA (PVA-PH) powder with a low, medium, and a high degree of polymerization. The observation process was conducted separately between these three different kinds of PVA. The pondering process was required to obtain the right amount of solution concentration. The observation was carried out for three different partial hydrolyzed PVA with three different levels of concentration each $(1,5$, and $10 \%)$. Magnetic hot plate and the magnetic bar were used in this experiment to help the solution process. The solution was created inside 1-Liter beaker glass with $300 \mathrm{~mL}$ of solvent. It constantly stirred by a magnetic stirrer bar before the PVA powder was put in. The preparation step was to weigh the PVA powder, then put it into beaker glass slowly, which contains an amount of demineralized water. During the dissolution process, periodically, take the sample every 5 minutes for several in-situ characterizations until the expected concentration of the PVA solution is reached. While for its solvent's components, the measurement was conducted once before observation started.

\section{Characterization}

Every component of PVA solution like $\mathrm{pH}$, conductivity, viscosity, solution weight, and dissolution time was measured using specific tools. The $\mathrm{pH}$ and conductivity values were measured by Conductometer Methrohm while the solid content was measured with Refractometer Atago as \% Brix with detection limit 0-53\%. The intrinsic and dynamic viscosity by Viscometer Ostwald and Viscometer Brookfield RVT, respectively. The dissolution time was measured against its solid content percentage. The structure molecule was determined by FTIR Spectrophotometer. ${ }^{21,22}$

The observation process was running simultaneously with the measurement process. Calibration was required for the tools used to measure the $\mathrm{pH}$ value. This calibration process should be done before measuring every other PVA solution. The value of $\mathrm{pH}$, temperatures, and conductivity from each PVA solution in running tests is obtained by checking screen overtime every 5 to 30 minutes.

\section{Result and Discussion}

First observation, as described in Figure 1, The dissolution time of PVA with partially hydrolyzed based for different concentration is 1 , 5 , and $10 \%$ respectively in aqueous solution at room temperature was evaluated. According to the observed result, dissolution time is dependent on the concentration of the PVA solution. The higher concentration of PVA will take a long time to dissolve completely. To make all PVA powder dissolve completely for $1 \%$ of PVA solution needs almost 40 minutes, then when the solid content increased to $5 \%$ needs 270 minutes. Meanwhile, the longest dissolution time is when the concentration of the PVA solution is $10 \%$ requires 360 minutes. The dissolution rate powder or solid-phase generally is influenced by temperature, agitation speed, and media environment.23,24 It confirmed the observation result was reported by Adeyinka Aina, who do the research about PVA solution in water. S. Aruldass also confirms the factors affecting the hydrolysis reaction of polyvinyl acetate to PVA. These reports concluded that higher temperature and agitation speed would increase the dissolution rate of PVA. ${ }^{24-26}$ When faster agitation produced a higher degree of hydrolysis caused, the higher degree of hydrolysis of PVA requires high-speed agitation to dissolve completely. ${ }^{24,26}$

Figure 1 states that various concentrations of PVA with partially hydrolyzed by the high degree of polymerization explained higher concentration take a long time to dissolve well. For the different degree of polymerization with the same various concentrations is exhibited in Figure 2. Each concentration requires a different dissolution rate to dissolve completely and as another confirmation that besides the concentration of PVA solution, the degree of polymerization also plays a role in the process of dissolution rate. ${ }^{27} \mathrm{~A}$ similar observation was explained by Molecular Association Studies at different concentrations on Polyvinyl Alcohol, while the research has shown time relaxation differences in PVA different concentrations. It explained clearly that different concentrations and the molecular weight is shown to affect time further. ${ }^{24,26}$ 


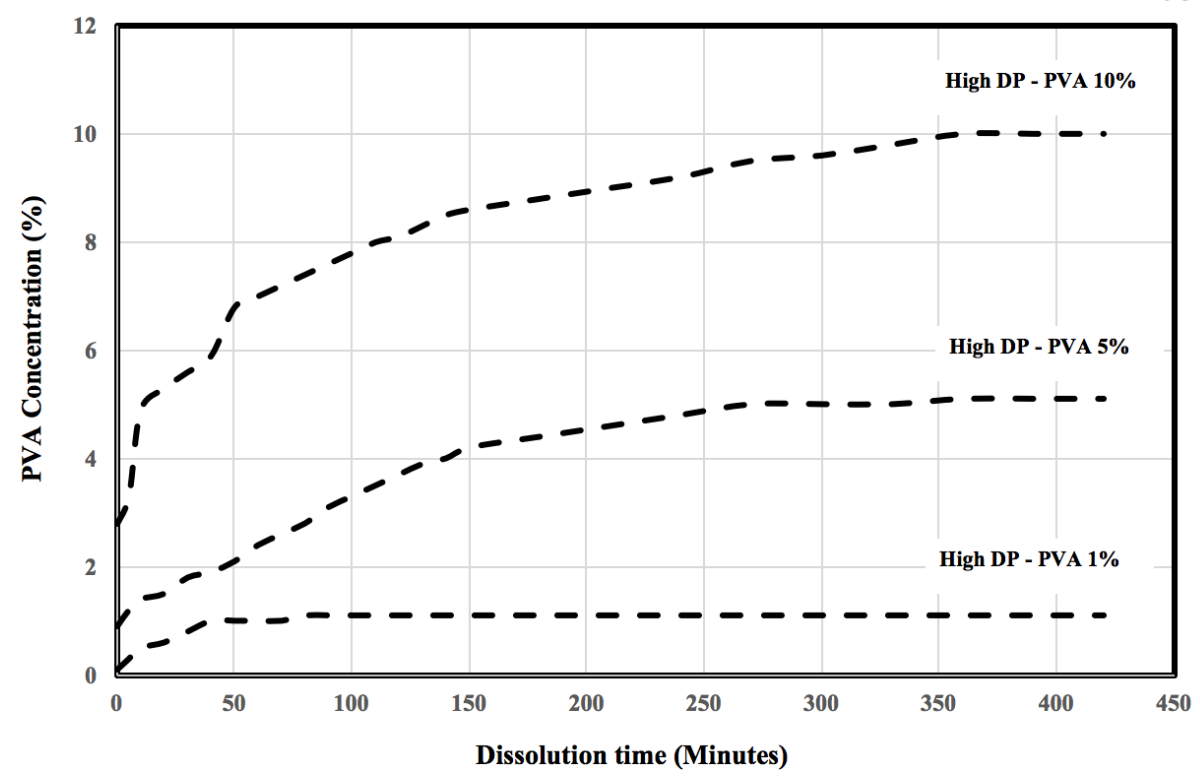

Figure 1. Dissolution Time of High Degree Polymerization for various concentrations.

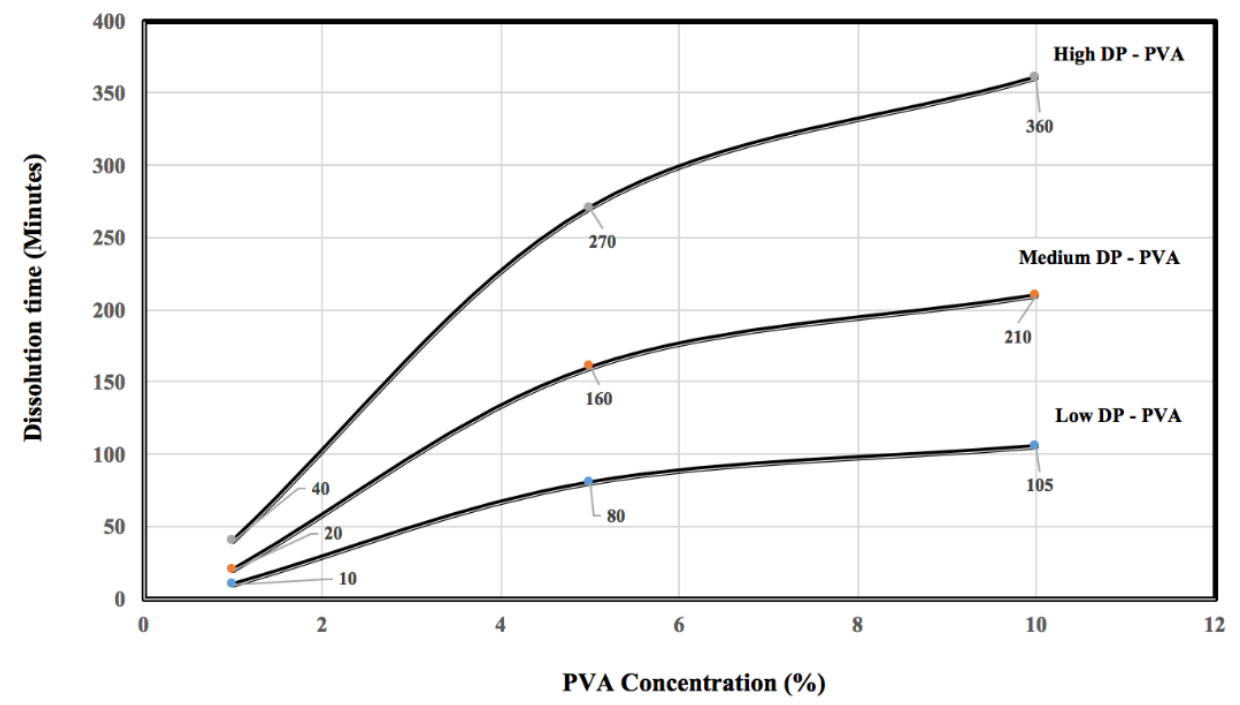

Figure 2. Dissolution Time of PVA types for various concentration.

Table 1. Viscosity Value concentrations various concentration

\begin{tabular}{lccc}
\hline \multirow{2}{*}{$\begin{array}{c}\text { Degree of Polymerization } \\
\text { (DP) }\end{array}$} & \multicolumn{3}{c}{ Solid Content, \% } \\
\cline { 2 - 4 } & \multicolumn{3}{c}{ Viscosity, mPa s } \\
\cline { 2 - 4 } & 1.2 & $\mathbf{1 0 \%}$ \\
\hline PVA Low - DP & 1.7 & 13.5 & 30.5 \\
\hline PVA Medium - DP & 2.6 & 39.7 & 1985 \\
\hline PVA High - DP & \multicolumn{3}{c}{}
\end{tabular}

Table 1 presented the viscosity value of each PVA solution with various concentrations and different degrees of polymerization. According to Figure 2 , it is confirmed that the highest viscosity was obtained for $10 \%$ of the solution with a high degree of polymerization by achieving $1985 \mathrm{mPa}$ s while the lower one is achieved by $1 \%$ of the solution with a lower degree of polymerization by $1.2 \mathrm{mPa}$ s for all viscosity value was measured at room temperature. PVA consists of hydrophilic and hydrophobic groups in its constituent molecules.

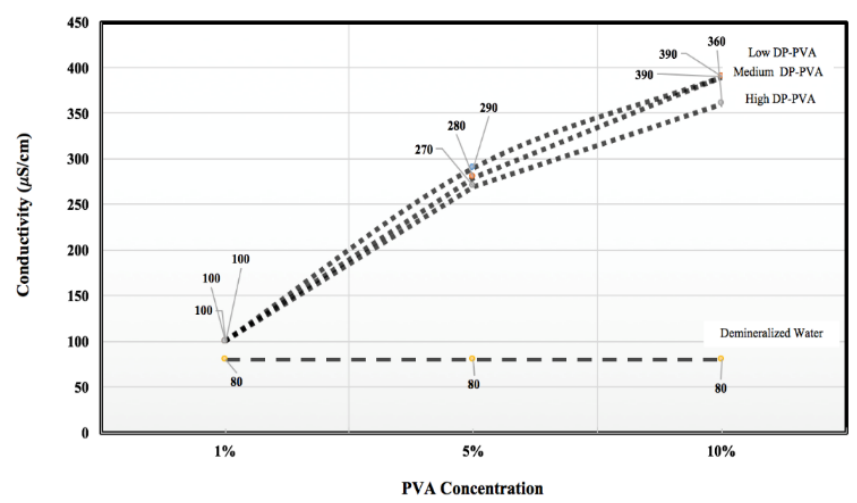

Figure 3. The conductivity of PVA types for various concentration. 
These are possible to control and arrange the viscosity, solubility property in water, and other properties by adjusting the degree of polymerization and degree of hydrolysis. ${ }^{28}$

The viscosity measurement was conducted through two types of the measurement unit. One method is using Viscometer Ostwald with a detection limit is $50 \mathrm{mPa}$ s and the second method is by processing measurement using Viscometer Brookfield RVT with a wider detection limit of measurement. When Viscometer Ostwald was applied, then the following equation used to determine the final viscosity value. ${ }^{29}$ $\eta_{y}=\eta_{w} \frac{d_{y} t_{y}}{d_{w} t_{w}}$

Whereas $\eta_{y}$ as the viscosity of the tested liquid, $\eta_{w}$ as the viscosity of water, $d$ is for density and $t$ for the timing of runoff liquid. The measurement was conducted every 5 to 30 minutes. Filtering the solution before pouring it into the Ostwald tube was necessary to avoid clogging. After the measurement, the solution sample was returned into the stirring process. Ostwald tube needs to be cleaned before conducting another measurement.

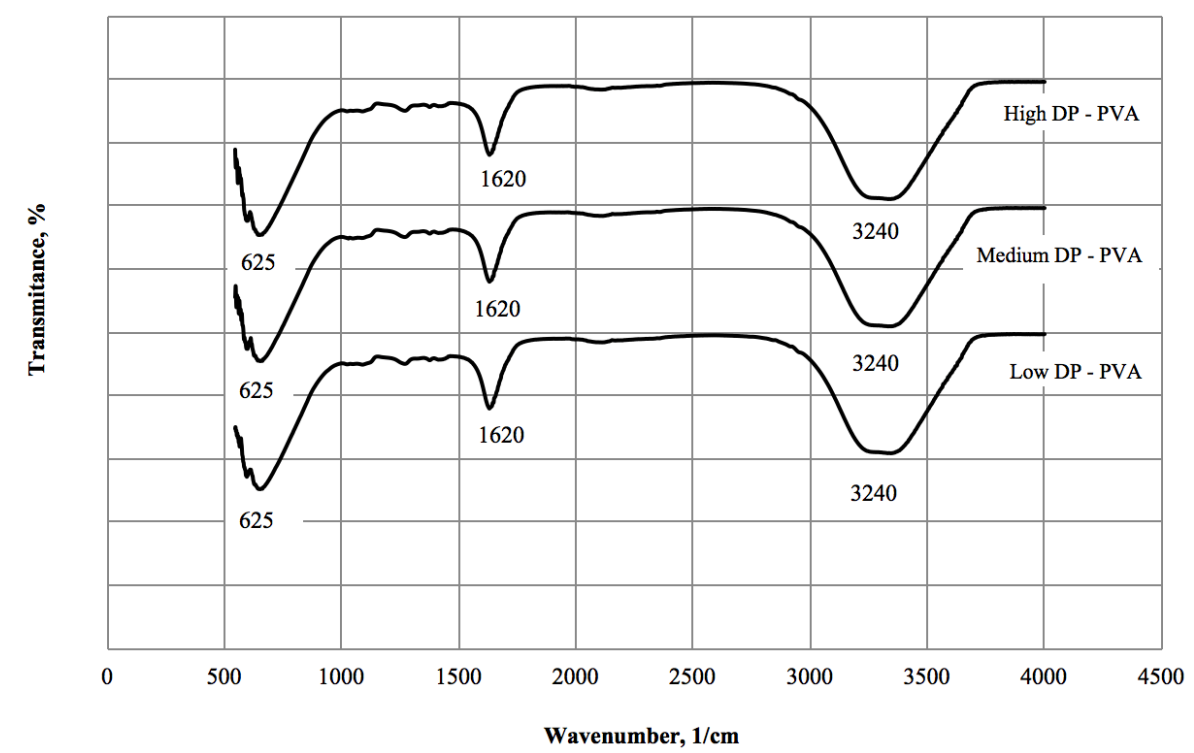

Figure 4. FTIR Spectrum of different Degree of Hydrolysis PVA in $10 \%$ solution.

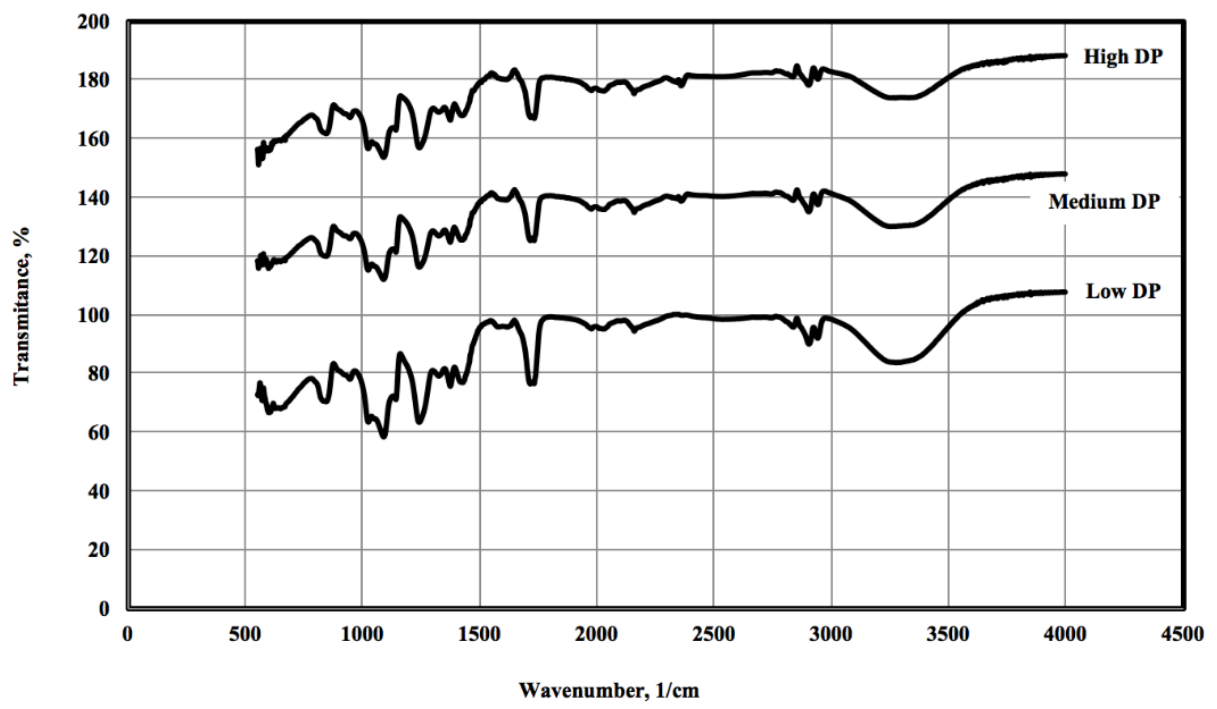

Figure 5. FTIR Spectrum of different Degree of Hydrolysis PVA Powder.

The results were confirmed with a polymer theory stated that the viscosity of polymer would be directly proportional to the degree of polymerization. The higher degree of polymerization of a polymer will have higher viscosity. ${ }^{13,30}$ For the purpose of obtaining the electrical properties of PVA in order to enhance the conductivity property of Polyaniline (PANI) and Polypyrrole (PPy), hence the electrical property evaluation was conducted during 
the dissolution process, and the summarized result is described in Figure 3 . Since the electrical conductivity containing a different PVA percentage was determined by the conductometer, hence the sample testing was measured in the aqueous phase.

Referring to Figure 3, when demineralized water is used as a reference and also as the only one solvent involved in the PVA solution has the conductivity value is $80 \mu \mathrm{sm}^{-1}$ at $27^{\circ} \mathrm{C}$ constantly for all varieties of PVA concentration. The conductivity value of pure water, as explained by Truman et al. that being affected by temperature, impurities that are containing mineral compounds, hydrogen ion mobilities, ionization constant, density, and resistivity. ${ }^{31,32}$ The solution when water and each PVA was a presence in the aqueous system caused the conductivity value of each PVA solution to have varying results.

According to the graph in Figure 3 exhibited that PVA concentration determines the conductivity value. The higher PVA concentration obtained a higher conductivity value, which applies to each type of PVA. While the difference in the degree of polymerization does not cause a significant difference in conductivity value when compared to the same PVA concentration. Conductivity is known as the measure of water's ability to conduct electricity, depending on the concentration of dissolved ions in the water. ${ }^{31,32}$ This is also in line with the report of Salman on the conductivity of PVA, which depends on the concentration. ${ }^{33}$

In order to know the molecular property of PVA molecule, the characterization of the PVA by the FTIR Spectrophotometer was conducted. Both powder and solution form were measured as described in Figure 4 and 5. It showed the absorption peaks of PVA at about $3240 \mathrm{~cm}^{-1}$ for $-\mathrm{OH}$ stretching and about 1620 and $625 \mathrm{~cm}^{-1}$ for the $-\mathrm{C}-\mathrm{O}$ group in solution form. While in the powder form presented the identical peaks for all PVA type. It is exhibited that either PVA solution or PVA powder has an identical spectrum for all types. The polymerization degree and degree of hydrolysis do not have any impact on the molecular structure of PVA. It's confirmed by the result of complete characterization for PVA through an infrared spectrum spectrophotometer. ${ }^{34}$

\section{Conclusions}

The study was conducted to analyse the effects of concentration and polymerization degree on dissolution time and conductivity in Partially Hydrolysed PVA at room temperatures. These effects were found to have an influence on both dissolution time and conductivity. The dissolution time increased with an increasing polymerization degree. Longer dissolution time has occurred at a higher concentration on a different polymerization degree in PVA. The low polymerization degree of PVA has higher conductivity than the high polymerization degree. Concentration increase has an increased effect on conductivity value. The conductivity value does not affect by PVA dissolution. The degree of polymerization of PVA is crucial as it affects the properties of the resulted PVA solution.

\section{Conflicts of Interest}

There are no conflicts to declare.

\section{Acknowledgments}

The authors gratefully acknowledge the support of the Postgraduate Program of Materials Science Universitas Indonesia for the research facilities. We are thankful for the financial support provided by the Directorate of Research and Community Service Universitas Indonesia under program Grants of International Publication Indexed 9 (PIT 9, 2019) under contract No. NKB002/UN2.R3.1/HKP.05.00/2019.

\section{References}

1 Z. Li and Y. W. Yang, Creation and Bioapplications of Porous Organic Polymer Materials, J. Mater. Chem. B., 2017, 5, 92789290.

2 J. Zhu, P. Zhu,C. Yan, X. Dong and X. Zhang, Recent Progress in Polymer Materials for Advanced Lithium-Sulfur Batteries, Prog. Polym. Sci., 2019, 90, 118-63.

3 H. Bai, H. Chen, R. Hu, M. Li, F. Lv, L. Liu and S. Wang, Supramolecular Conjugated Polymer Materials for In-Situ Pathogen Detection, ACS Appl. Mater. Interfaces. 2016, 8, 31550-31557.

4 I. E. Suleymenov, Z. Z. Sedlakova and E. E. Kopishev, New Polymer Materials for Optical Sensor Systems, J. Inorg. Organomet. Polym. Mater., 2019, 29, 758-764.

5 H. T.Ananda, G. T. Urs and R. Somashekar, Preparation and Characterization of Conductive PVA/Gly: $\mathrm{Na}_{2} \mathrm{SO}_{4}$ Polymer Composites, Polym. Bull., 2016, 73, 1151-1165.

6 M. Ng, H. Kwan, C. P. Leo, S. N. M. A. Senanayake, G. K. Lim and M. K. Tan, Carbon-Dot Dispersal in PVA Thin Film For Food Colorant Sensing, J. Environ. Chem. Eng., 2019, 103187.

7 B. Ding, H-Y. Kim, S-C. Lee, D-R. Lee and K-J. Choi, Preparation and Characterization of Nanoscaled Poly(Vinyl Alcohol) Fibers via Electrospinning, Fibers Polym., 2002, 3, 73-79.

8 T. Chandy and C. P. Sharma, Prostaglandin E1-Immobilized Poly(Vinyl Alcohol)-Blended Chitosan Membranes: Blood Compatibility and Permeability Properties, J. Appl. Polym. Sci., 1992, 44, 2145-2156.

9 K. M. Manikandan and A. S. Yelilarasi, The Conducting Polymer Electrolyte Based on Polypyrrole-Polyvinyl Alcohol and Its Application in Low-Cost Quasi-Solid-State Dye-Sensitized Solar Cells, J. Solid State Electrochem, 2016, 22, 3785-3797.

10 T. S. Tsai, V. Pillay, Y. E. Choonara, L. C. du Toit, G. Modi, D. Naidoo and P. Kumar, A Polyvinyl Alcohol-Polyaniline Based Electro-Conductive Hydrogel for Controlled Stimuli-Actuable Release of Indomethacin. Polymers (Basel), 2011, 3, 150-172.

11 C. C. Demerlis and D. R. Schoneker, Review of the Oral Toxicity of Polyvinyl Alcohol (PVA), Food Chem Toxicol, 2003, 41, 319326.

12 T. S. Gaaz, A. B. Sulong, M. N. Akhtar, A. A. H. Kadhum, A. B. Mohamad, A. A. Al-Amiery and D. J. McPhee, Properties and Applications of Polyvinyl Alcohol, Halloysite Nanotubes and Their Nanocomposites, Molecules, 2015, 20, 22833-22847.

13 B. M. Budhlall, K. Landfester, E. D. Sudol, V. L. Dimonie, A. Klein and M. S. El-Aasser, Characterization of Partially Hydrolyzed Poly(vinyl alcohol). Effect of Poly(vinyl alcohol) Molecular Architecture on Aqueous Phase Conformation, Macromolecules, 2003, 36, 25, 9477-9484. 
14 S. A. Umoren, I. B. Obot, A. Madhankumar and Z. M. Gasem, Effect of Degree of Hydrolysis of Polyvinyl Alcohol on the Corrosion Inhibition of Steel: Theoretical and Experimental Studies, J. Adhes. Sci. Technol., 2015, 29, 271-295.

15 F. Liu, T. Nishikawa, W. Shimizu, T. Sato, H. Usami, S. Amiya, Q. Q. Ni and Y. Murakami, Preparation of Fully Hydrolyzed Polyvinyl Alcohol Electrospun Nanofibers with Diameters of Sub-200 nm by Viscosity Control, Text. Res. J., 2012, 82, 1635-1644.

16 G. El-Kodsi and J. Schurz, Chemical Characterization of High Polymers. Nitration and Subsequent Reactions, Papier (Darmstadt), 1973, 27, 253-255 [Chem. Abstr., 79, 54022h] (in German).

17 S. Baek, Y. Id, S. H. Yoo, J. S. Lee, J. W. Kim and J. H. Yeum, Surface Properties of a Novel Poly (Vinyl Alcohol) Film Prepared by Heterogeneous Saponification of Poly (Vinyl Acetate) Film, Polymers, 2017, 9, 493.

18 J. M. Zhang, H. J. Li, Z. Y. Gao and N. Li, The Preparation and Research of PVA Embedding Zr-AC Phosphorus Adsorbent, Appl. Mech. Mater., 2011, 90-93, 2438-2443.

19 D. A. Bichara, H. Bodugoz-sentruk, D. Ling, and E. Malchau, Osteochondral Defect Repair Using a Polyvinyl Alcohol-Polyacrylic Acid (PVA-Paac) Hydrogel, Biomed. Mater., 2014, 9, 045012.

20 S. Saxena, Polyvinyl Alcohol (PVA), Food and Agriculture Organization of the United Nations, Chemical and Technical Assessment (CTA), 2004, 61, 1-5.

21 T. Aging and A. Munajad, Fourier Transform Infrared (FTIR) Spectroscopy Analysis of Transformer Paper in Mineral Oil-Paper Composite Insulation Under Accelerated, Energies, 2018, 11, 364 .

22 D. Ami, P. Mereghetti, M. Leri, S. Giorgetti, A. Natalello, S. M. Doglia, M. Stefani and M. Bucciantini, A FTIR Microspectroscopy Study of the Structural and Biochemical Perturbations Induced by Natively Folded and Aggregated Transthyretin in HL-1 Cardiomyocytes, Sci. Rep., 2018, 1-15.

23 S. Aruldass, V. Mathivanan, A. R. Mohamed, and C. T. Tye, Factors Affecting Hydrolysis of Polyvinyl Acetate to Polyvinyl Alcohol, J. Environ. Chem. Eng., 2019, 7, 103238.
24 A. Koski, K. Yim, and S. Shivkumar, Effect of Molecular Weight on Fibrous PVA Produced by Electrospinning, Mater. Lett., 2004, 58, 493-497.

25 A. Aina, A. Morris, M. Gupta, N. Billa, and N. Madhvani, Dissolution Behavior of Poly Vinyl Alcohol in Water and Its Effect on the Physical Morphologies of PLGA Scaffolds. UK Journal of Pharmaceutical and Biosciences, 2014, 2, 1-6.

26 R. Saxena and S. C. Bhatt, Molecular Association Studies on Polyvinyl Alcohol at Different Concentrations, Adv. Mater. Sci. Eng., 2018. 1738612.

27 J. Liang and R. Chen, Impact of Cross-Linking Mode on the Physical Properties of Zein/PVA Composite Films. Food Packag. Shelf Life, 2018, 18, 101-106.

28 Y. Shi, D. S. Xiong, Y. Peng and N. Wang, Effects of Polymerization Degree on Recovery Behavior of PVA/PVP Hydrogels as Potential Articular Cartilage Prosthesis After Fatigue Test, Express Polym. Lett., 2016, 10, 125-138.

29 M. Verma, N. Wasnik, T. Sai Sneha and S. Rajalingam, Measurement of Viscosity for Various Liquids by Using Ostwald Viscometer and Interfacing with Labview, Int. J. Appl. Eng. Res., 2013, 8, 2369-2372.

30 S. Ogawa, M. Koga and S. Osanai, Anomalous Ice Nucleation Behavior in Aqueous Polyvinyl Alcohol Solutions, Chem. Phys. Lett., 2009, 480, 86-89.

31 T. S. Light, S. Licht, A. C. Bevilacqua and K. R. Morash, The fundamental conductivity and resistivity of water, Electrochem. Solid-State Lett., 2005, 8, 16-19.

32 Thermo Fisher Scientific, 2017, Measuring the Conductivity of Pure Water Using USP<645>, Thermo Fisher Sci. Appl., Notes.

33 S. A. Salman, N. A. Bakr and M. H. Mahmood, Preparation and Study of some Electrical Properties of PVA-Ni( $\left(\mathrm{NO}_{3}\right)_{2}$ Composites, Int. Lett. Chem. Phys. Astron., 2014, 40, 36-42.

34 E. Fonseca Dos Reis, F. S. Campos, A. Pereira Lage, R. Cerqueira Leite, L. Guilherme Heneine, Z. Ines, P. Lobato and H. S. Mansur, Synthesis and Characterization of Poly (Vinyl Alcohol) Hydrogels and Hybrids for rMPB70 Protein Adsorption. Mater. Res., 2006, 9, 185-191. 